\title{
NITRATE-SELECTIVE ELECTRODES BASED ON THE TRINUCLEAR CHROMIUM(III) PIVALATES
}

\author{
Mihail Revenco $^{\text {a*}}$, Mariana Martin ${ }^{\mathrm{a}}$, Waell A.A. Dayyih ${ }^{\mathrm{b}}$ \\ ${ }^{a}$ State University of Moldova, A.Mateevici street, 60 MD 2009, Chisinau, Republic of Moldova \\ ${ }^{b}$ University Petra, Amman, Jordan \\ *E-mail: revenco@usm.md; phone 373-22-57-74-94, 373-22-43-22-98, 373-69-19-48-91;
}

fax $373-22-24-42-48$

\begin{abstract}
The paper describes the analytical potentialities of the trinuclear chromium(III) complexes as potentiometric ionophores for the construction of electrodes sensitive to the presence of nitrate anion. The electroactive material containing 4,4'-bipyridil was synthesized in situ. The membrane was prepared using dioctylphthalate as a solvent mediator and poly (vinyl chloride) as a polymeric matrix. The electrodes presented a slope of $56 \mathrm{mV} / \mathrm{decade}$, a low limit of detection $\left(3,2 \cdot 10^{-6} \mathrm{~mol} / \mathrm{l}\right)$, an adequate lifetime (4 months), and suitable selectivity characteristics when compared with other nitrate electrodes. The good parameters of this electrode made possible its application to the determination of nitrate in different types of fertilizers.
\end{abstract}

Keywords: Trinuclear chromium(III) pivalate, nitrate-sensors.

\section{Introduction}

Nitrate is an anion of major importance in environmental and biological areas. The necessity for nitrate monitoring in drinking water and food products is recognized by most health authorities. This ion, after chemical transformation, could have a direct impact on health because of its reaction with amines to produce nitrosamines, which are known to be one of the most powerful carcinogens to mammalians. This is why, a lot of various methods including spectrophotometry, electrochemical methods based on modified electrodes and nitrate-selective electrodes have been developed for the determination of nitrate in different samples. Among these methods, potentiometric detection using the ion-selective electrodes [1-5] provides a rapid, simple, reasonably selective and inexpensive way for determination the content of this ion.

Recently the trinuclear chromium(III) benzoates were investigated as ionophores in the membrane of the anionic sensors [7]. The lipophilic complex cation can be combined with some inorganic and organic anions, which are part of a number of pharmaceutical materials. Variation of the carboxylic acid anion and use of different amines offer a real possibility to elaborate new sensors of high performance level. Recently we have described an electrode, sensitive to the presence of the perchlorate anion, based on the trinuclear chromium(III) pivalates [8].

Therefore, using this type of chromium(III) complexes, we were prompted to study the response of a membrane to the presence of nitrate anions. One of these electrodes shows improved selectivity for some of the interferences when compared with those for the commercially available nitrate-selective electrodes.

\section{Experimental \\ Reagents and solutions}

Dioctylphtalate (DOP) and poly (vinyl chloride) (PVC) of relative high molecular weight were used. All the reagents and solvents were of analytical reagent grade.

A standard nitrate solution $(0,1 \mathrm{~mol} / \mathrm{l})$ was prepared by carefully weighing solid sodium nitrate. Standard solutions of all other anions were prepared from their respective sodium or potassium salts as $0,1 \mathrm{~mol} / 1$ stock solutions. The $\mathrm{pH}$ adjustments were made with dilute sulphuric acid or sodium hydroxide solutions, as required. All solutions were prepared with twice distilled water.

\section{Synthesis of ionophores}

The initial compound - $\left[\mathrm{Cr}_{3} \mathrm{O}\left(\mathrm{C}_{5} \mathrm{H}_{9} \mathrm{O}_{2}\right)_{6}\left(\mathrm{H}_{2} \mathrm{O}\right)_{3}\right] \mathrm{NO}_{3}$, (I) - was prepared using the described previously procedure [9] by dissolving $2 \mathrm{~g}$ of $\left[\mathrm{Cr}_{3} \mathrm{O}\left(\mathrm{C}_{5} \mathrm{H}_{9} \mathrm{O}_{2}\right)_{6}\left(\mathrm{H}_{2} \mathrm{O}\right)_{3}\right] \mathrm{C}_{5} \mathrm{H}_{9} \mathrm{O}_{2}$ in $10 \mathrm{ml}$ acetone, containing $0,5 \mathrm{ml}$ of $\mathrm{HNO}_{3}$ solution (31\%). The precipitated green crystals were filtered and washed with ether.

The compounds $\left[\mathrm{Cr}_{3} \mathrm{O}\left(\mathrm{C}_{5} \mathrm{H}_{9} \mathrm{O}_{2}\right)_{6}\left(\mathrm{C}_{9} \mathrm{H}_{7} \mathrm{~N}\right)_{3}\right] \mathrm{NO}_{3}$ II and $\left[\mathrm{Cr}_{3} \mathrm{O}\left(\mathrm{C}_{5} \mathrm{H}_{9} \mathrm{O}_{2}\right)_{6}\left(\mathrm{C}_{10} \mathrm{H}_{8} \mathrm{~N}_{2}\right)_{3}\right] \mathrm{NO}_{3}$ (III) were prepared by dissolving $\mathbf{I}$ in acetone and addition of quinoline or 4,4'-bipyridil in stoechiometric ratio. The precipitated after a slow evaporation complexes were filtered, washed and dried at $105^{\circ} \mathrm{C}$. The composition of the complexes has been confirmed by the elemental analysis for $\mathrm{C}, \mathrm{H}, \mathrm{N}$, and $\mathrm{Cr}$.

The complexes I and II are soluble in ethanol, acetone, tetrahydrofuran (THF), nitrobenzene (NB), while the compound III is poorly soluble in this solvents. All pivalates are insoluble in water. 


\section{Preparation of the electrodes}

The PVC membrane electrodes were prepared using a procedure similar to those described ???

The mixture of PVC cocktail, prepared by dissolving 0,02 - 0,03 $\mathrm{g}$ ionophore, 0,3 $\mathrm{g}$ PVC, 0,3 $\mathrm{g}$ DOP, and $0,9 \mathrm{~g}$ nitrobenzene in $3-5 \mathrm{ml}$ of tetrahydrofuran (THF), was poured onto a glass dish (ca. $5 \mathrm{~cm}$ diameter) and allowed to dry at room temperature. A membrane (ca.16 mm diameter) was cut and glued to the polished end of a PVC tube by using a PVC (ca. $5 \%$ ) - THF solution. According to the number of complexes used for preparation of the membrane the ion selective electrodes (ISE) are noted as (ISE1, ISE2 and ISE3). The $\mathrm{Ag} / \mathrm{AgCl}$ electrode and $10^{-1} \mathrm{M}^{\circ} \mathrm{NO}_{3}^{-}+5 \cdot 10^{-3} \mathrm{M}$ of $\mathrm{KCl}$ solution were used as reference electrode and the internal filing solution, respectively.

The assembled electrodes were conditioned by soaking into solution of sodium nitrate $\left(10^{-1} \mathrm{M}\right)$ for $12 \mathrm{~h}$ before the electrodes have been used.

\section{Measurement of electromotive force}

A nitrate-selective $\mathrm{PVC}$ electrode and saturated $\mathrm{Ag} / \mathrm{AgCl}$ electrode were used as the indicating and the reference electrode, respectively. All potential measurements were performed at an ambient temperature $\left(25 \pm 1^{\circ} \mathrm{C}\right)$ using a galvanic cell of the following type: $\mathrm{AgCl} / \mathrm{Ag}$.

$\mathrm{Ag} / \mathrm{AgCl}, \mathrm{KCl}\left(5 \cdot 10^{-3} \mathrm{M}\right) \mid$ internal filing solution $\left(10^{-1} \mathrm{M} \mathrm{NO}_{3}^{-}\right) \mid \mathrm{PVC}$ membrane $\|$ tested solution $\| \mathrm{KCl}$ satd.

The behavior of each electrode was investigated in the concentration range of $1 \cdot 10^{-7}-1 \cdot 10^{-1} \mathrm{M}$ at a constant $\mathrm{pH}$. The data were plotted as the observed potential against the negative logarithm of the $\mathrm{NO}_{3}^{-}$activity. The potentiometric coefficients $\left(\mathrm{KNO}_{3}^{-} / \mathrm{X}^{-}\right)$were determined according to the fixed interference method.

\section{Results and discussion}

Influence of the nature of the ligand in the apical position of the trinuclear cromium(III) pivalates on the sensors parameters

The potentiometric response of the ISE1 was linear Nernstian in the concentration range $8 \cdot 10^{-5}-1 \cdot 10^{-1} \mathrm{M}$ with a slope $50 \mathrm{mV} /$ decade. The detection limit was $3,2 \cdot 10^{-5} \mathrm{~mol} / 1$ and the electrode lifetime - only one day. We explain this short lifetime, by the possible hydrolysis of the complex and loss of the charge by the complex species according to the scheme:

$$
\left[\mathrm{Cr}_{3} \mathrm{O}\left(\mathrm{C}_{5} \mathrm{H}_{9} \mathrm{O}_{2}\right)_{6}\left(\mathrm{H}_{2} \mathrm{O}\right)_{3}\right]^{+}+\mathrm{H}_{2} \mathrm{O} \rightarrow\left[\mathrm{Cr}_{3} \mathrm{O}\left(\mathrm{C}_{5} \mathrm{H}_{9} \mathrm{O}_{2}\right)_{6}\left(\mathrm{H}_{2} \mathrm{O}\right)_{2}(\mathrm{OH})\right]+\mathrm{H}_{3} \mathrm{O}^{+} \text {. }
$$

The substitution of the co-ordinated water by quinoline in ISE2 gives rise to an increase of the lipophilic properties of the complex, extending his lifetime up to 7 day and diminishing the detection limit up to $2 \cdot 10^{-5} \mathrm{M}$, similar to the behavior of the electrodes described in $[7,8]$.

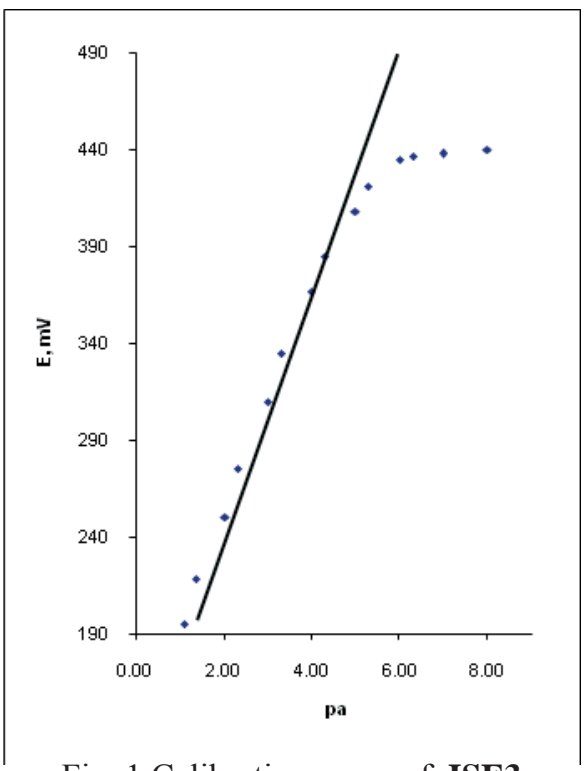

Fig. 1 Calibration curve of ISE3

Although the substitution of the water molecules by quinoline improves the parameters of the sensor, the lifetime is short enough. A possible washing-out of the electroactive material could be the cause of this relatively short lifetime. To stabilize the ionophore in membrane, we have tried the polymerisation of the trinuclear cores using bridging ligands. 
The 4,4'-bipiridil was suitable for this purpose. The interaction of pivalate I with 4,4'-bipyridil in stoechiometric ration $2: 3$, leads to formation of a product III, which one is poorly soluble both in water and in the used for preparation the membrane solvents. Use of a saturate in nitrobenzene solution and incorporated in membrane, does not gives rise to a nitrates sensitive electrode. This behavior demonstrates the formation of a polymer with very low solubility, which cannot assure a sufficient concentration to prepare a PVC membrane.

To achieve the objective we have tried the synthesis of the active material in situ [8], directly in membrane during its formation. The complex I, 4,4'-bipiridil and the other components used for preparation of the membrane of ISEI, all together, were mixed stirred and left for evaporation. During this time part of water molecules was substituted by 4,4'- bipyridil, and a new polymeric structure has appeared and plays the role of ionophore. We suppose, that the presence of the PVC does not allow the formation of the crystalline polymer, but it ensures the lacing of a number of trinuclear unities encapsulated by the solvent containing nitrate as counter ion.

Washing-out of this compound from membrane is surely hindered. The potentiometric response of ISE3,

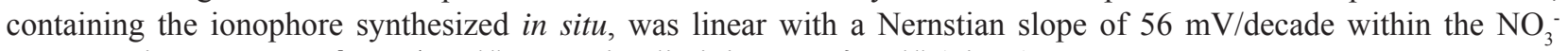
concentration range $2 \cdot 10^{-5}-1 \cdot 10^{-1} \mathrm{~mol} / \mathrm{l}$. Detection limit is $3,2 \cdot 10^{-6} \mathrm{~mol} / \mathrm{l}$ (Fig. 1 ).

The reponse time of the electrode was $\leq 15 \mathrm{~s}$ over the entire linear concentration range of the calibration plot. In order to study the effect of $\mathrm{pH}$ on the performance of ISE3, the responses of the sensor to $\mathrm{NO}_{3}^{-}$ion at different concentrations of $\mathrm{H}^{+}$ion were measured. It was observed that the sensor exhibite a stable behavior with a constant potential in the $\mathrm{pH}$ range $2-11$. The Fig. 2 shows the variation of the potential of the sensors immersed in a solution with the concentration $0,001 \mathrm{M}$. To achieve stable parameters the preconditioning time must be close to $12 \mathrm{~h}$ in a 0,1 $\mathrm{mol} / \mathrm{l}$ solution of $\mathrm{NaNO}_{3}$. The drift of the potential for a constant concentration is negligible. The electrodes prepared by this method show stable parameters during 4 months. During this period, the electrode was kept in a $0,1 \mathrm{~mol} / 1 \mathrm{NaNO}_{3}$ solution and calibrated periodically. No significant change in the performance of the electrode was observed.

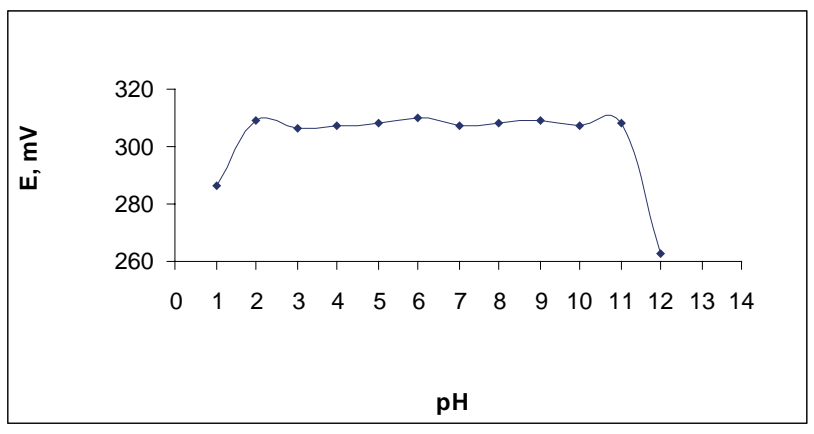

Fig.2 Influience of $\mathrm{pH}$ on the response of the ISE3 immersed in a solution of $\mathrm{NaNO}_{3}(0,001 \mathrm{M})$

The performances of a selection of different electrodes published in literature are shown in the Table 1. As it can be observed the parameters of the proposed electrode are comparable with of available nitrate-selective electrodes.

Table 1

Parameters of a selectoion of nitrate-selective electrodes

\begin{tabular}{|c|c|c|c|c|c|}
\hline Concentration range, mol/l & Slope, $\mathbf{m V} /$ decade & Detection limit, mol/l & $\mathbf{p H}$ range & Lifetime & Reference \\
\hline $1 \cdot 10^{-1}-1 \cdot 10^{-6}$ & & $3,4 \cdot 10^{-7}$ & $2-8$ & {$[1]$} \\
\hline $1 \cdot 10^{-1}-2 \cdot 10^{-5}$ & 58 & & $5-11$ & {$[2]$} \\
\hline & 60 & $4,2 \cdot 10^{-6}$ & & 1 year & {$[3]$} \\
\hline & $54-55$ & $5,0 \cdot 10^{-5}$ & & {$[4]$} \\
\hline $1 \cdot 10^{-1}-1 \cdot 10^{-5}$ & 54,7 & $2,3 \cdot 10^{-6}$ & $2-12$ & {$[5]$} \\
\hline $1 \cdot 10^{-1}-2 \cdot 10^{-5}$ & 56 & $3,2 \cdot 10^{-6}$ & $2-11$ & 4 months & ISE3 \\
\hline
\end{tabular}

Selectivity of the electrode ISE3

The potentiometric selectivity coefficients were determined by fixed interference method [10]. The potentiometric selectivity coefficients of the proposed electrode are summarized in table 2.

Table 2

Selectivity coefficients $\left(-\lg \mathrm{KNO}_{3}^{-} / \mathrm{X}^{-}\right)$of EIS 3 determined using fixed interference method

\begin{tabular}{|c|c|c|c|c|c|c|c|c|c|}
\hline $\mathrm{X}$ & $\mathrm{ClO}_{4}^{-}$ & $\mathrm{I}^{-}$ & $\mathrm{SCN}^{-}$ & $\mathrm{Br}$ & $\mathrm{BF}_{4}^{-}$ & $\mathrm{Cl}^{-}$ & $\mathrm{CH}_{3} \mathrm{COO}^{-}$ & $\mathrm{SO}_{4}^{2-}$ & $\mathrm{F}^{-}$ \\
\hline$-\lg \mathrm{NO}_{\mathrm{N}, \mathrm{X}}$ & 0,83 & 1,05 & 1,14 & 1,38 & 1,83 & 3,71 & 3,83 & 4,17 & 4,65 \\
\hline
\end{tabular}


The reason for selecting these ions was their presence in the environment when (in drinking water, fertilizers, fountain waters, industrial effluents, soils, etc.). The proposed electrode doesn't demonstrate a significant deviation in the selectivity from the Hofmeister series $\mathrm{ClO}_{4}^{-}>\mathrm{I}^{-}>\mathrm{SCN}^{-}>\mathrm{Br}^{-}>\mathrm{BF}_{4}^{-}>\mathrm{Cl}^{-}>\mathrm{CH}_{3} \mathrm{COO}^{-}>\mathrm{SO}_{4}^{2-}>\mathrm{F}^{-}$. The main interfering anions were found to be perchlorate, iodide and thiocyanate and this selectivity is similar to commercial nitrat selective electrode [2].

Analytical applications table 3

To assess the applicability of the proposed electrode for the analysis of the real samples, an attempt was made to determine nitrate contents in fertilizer - ammonium nitrate.

Direct potentiometry - before use, EIS3 was calibrated by measuring a series of known standard solutions (6) in the conditions of constant ionic strength ensured by sodium sulfate solution $0,1 \mathrm{M}$. The equation of the calibration

$56,19\left(-\log C_{x}\right)+139,33$, where $E_{x}$ is measured potential $(m V), C_{x}-$ concentration $(\mathrm{mol} / 1)$. A known mass of fertilizer was dissolved in a volumetric flask of $100 \mathrm{~cm}^{3}$ and adjusted to the mark with distilled water. Using ISE3 and the above mentioned galvanic cell, the potential $\mathrm{E}_{\mathrm{x}}$ was measured. The concentration of the nitrate was calculated using the equation of the calibration curve. The values of $\mathrm{E}_{\mathrm{x}}$ and the calculated concentration are given in the table 3 .

Table 3

Determination of nitrate in fertilizer - $\mathrm{NH}_{4} \mathrm{NO}_{3}$

\begin{tabular}{|c|c|c|c|c|c|}
\hline \multirow{2}{*}{$\mathrm{m}$ (fertilizer), $\mathrm{g}$} & \multirow{2}{*}{$\mathrm{E}_{\mathrm{x}, \mathrm{mV}}$} & \multicolumn{2}{|c|}{ Concentration, $\mathrm{mol} / 1$} & \multicolumn{2}{|c|}{$\omega\left(\mathrm{NH}_{4} \mathrm{NO}_{3}\right), \%$} \\
\cline { 3 - 6 } & 237 & $\mathrm{C}\left(\mathrm{NO}_{3}^{-}\right)$pot & $\mathrm{C}\left(\mathrm{NH}_{4}^{+}\right)$tit & potentiometry & titrimetry \\
\hline 0,1524 & 238 & 0,01827 & 0,0182 & 95,92 & 95,60 \\
& 234 & 0,01756 & & 92,19 & 95,37 \\
\hline 0,1770 & 244 & 0,02066 & 0,0211 & 93,38 & 94,42 \\
\hline 0,1135 & 245 & 0,01316 & 0,0134 & 96,70 & $95,1 \pm 0,4$ \\
\hline
\end{tabular}

For comparison and confirmation of the potentiometric data the determination of the using the titrimetric method. A aliquot of the solution containing $\mathrm{NH}_{4}^{+}$was made basic, and the liberated $\mathrm{NH}_{3}$ was distilled into receiver containing a known amount of $\mathrm{H}_{2} \mathrm{SO}_{4}$. Unreacted acid was then titrated with standard $\mathrm{NaOH}$ solution [11]. The results recorded by the potentiometric method agree reasonably well with those obtained using titrimetry. The advantage of potentiometric method consists in the short time spent for analysis and reliable results.

\section{Conclusion}

The reaction of the triaqua-hexapivalato-tri- $\mu$-oxo-trichromium(III) nitrate with 4,4'-bipyridyl in situ during the formation of the plastisized PVC membrane gives rise to a nitrate potentiometric sensor with good operating characteristics (sensitivity, stability, life time and response time), able to be used for potentiometric determination of this ion.

\section{References}

[1] Braven J., Ebdon L., Scholefield D. High-performance nitrate-selective electrodes containing immobilized amino acid betaines as sensors. Anal. Chem., 2002 Jun, V 74, p. 2596-2602.

[2] Asgari A., Amini M., Mansour H. Nitrate-selective membrane electrode based on bis(2-hydroxyanil)acetylacetone lead(II) neutral carrier. Analytical Sciences, 2003 august, V 19, p. 1121-1125.

[3] Kong Thoo L., Araujo A., Montenegro M. New PVC nitrat-selective electrode: aplication to vegetable and mineral waters. Agric. Food Chem., 2005 Jan, V 26, p. 211-216.

[4] Bendikov T., Harmon T. A sensitive nitrate ion-selective electrode from a pencil lead. Journal of Chemical Education, 2005 March, V 82, p. 439.

[5] Ortuno J., Exposito R., Sanchez-Pedreno C. A nitrate-selective electrode based on a tris(2-aminoethyl)amine triamide derivative receptor. Anal. Chim. Acta, 2004 november, V 525, p. 231-237.

[6] Revenco M., Martin M. Noi materiale electroactive pentru membranele senzorilor potențiometrici. Analele ştiințifice ale Universității de Stat din Moldova, Seria „Ş̦tiințe reale”, Lucrări de sinteză 1996-2006, Chişinău, 2006, p.90-97.

[7] Wael Ahmad Abu Dayyih. Potentiometric sensors based on polynuclear complex compounds for determination of some drug-substances. Ph.D. Thesis, State University of Moldova, Chisinau, 2002.

[8] Revenco M., Martin M. Senzori potențiometrici pentru determinarea percloraților. Analele ştiințifice ale Universității de Stat din Moldova, Seria „Ştiințe chimico-biologice”, Chişinău, 2006, p.480-483

[9] Simonov Yu., Bourosh P., Timco G. Synthesis, structure and mass-spectrometric-investigation of chromium trinuclear $\mu$-oxo-carboxylates. Chem. Bull., Romania 1998, V 43, p. 128-136.

[10] Камман К. Работа с ионселективными электродами, М:, Мир 1980, 283 с.

[11] Harris D. Quantitative Chemical Analysis, New York, Freeman and Company 1998, p.1025. 